\title{
Genetic Polymorphisms and Haplotype Analysis of Sweet Taste Receptor TASIR2 Gene in the Korean Population
}

\author{
Hye-Jin Lee ${ }^{\dagger}$, Jae-Woong Bae ${ }^{\dagger}$, Tae-Jun Kwon, Borum Sagong and Un-Kyung Kim*
}

\section{Department of Biology, Kyungpook National University Daegu 702-701, Korea}

Received January 4, 2010 /Accepted January 25, 2010

\begin{abstract}
Sweetness plays an important role in providing calories and promoting appetite for food. Since it has been known that genetic factor (s) is involved in individual differences in taste sensitivity in humans, this study aimed to examine genetic variations of the TAS1R2 gene, one of the components for tasting sweet compounds, by using DNA sequencing analysis from 98 unrelated Korean subjects. As a result, 12 different single nucleotide polymorphisms (SNPs) were identified in the hTAS1R2 gene and most of them were nonsynonymous. Also, two novel SNPs were found for the first time in this study. It was noted that the frequencies of these SNPs were common in the Korean population. 20 different haplotypes with coding SNPs (cSNPs) were also found in this study. Three out of these haplotypes were common, showing frequencies of $>10 \%$. The repertoire and frequencies of cSNPs and haplotypes in the $h T A S 1 R 2$ gene will provide information that will help identify a functional ligand receptor common in the Korean population.
\end{abstract}

Key words : Taste perception, sweet, TAS1R2 gene, single nucleotide polymorphism, haplotype

\section{서 론}

미각은 음식을 섭취할 것인가 거부할 것인가에 대한 결정에 중요한 감각 정보를 제공함으로써 우리 몸 내부 환경으로 통 하는 관문의 역할을 하며, 여러 가지 맛의 특성들과 그것에 의해 유발된 행동들은 에너지를 공급하고 적당한 전해질 및 산도를 유지시키고 독소를 회피하도록 도와주어 생물체의 생 존을 위한 필수적인 역할을 담당하는 중요한 감각이다. 인간 은 단맛, 쓴맛, 짠맛, 신맛, 그리고 감칠맛을 느낄 수 있는데, 이 중에서 단맛(sweet taste)은 인체의 열량을 제공하며 식욕 을 좌우하는 매우 중요한 요인이다. 최근 밝혀진 바에 따르면, 단맛을 인지하는 분자생물학적 메커니즘은 이들 분자들이 TAS1R2와 TAS1R3로 구성된 수용체에 결합하여 단백질의 구 조가 바뀌면서 2차 전달물질이 생성된 뒤 일련의 과정을 거쳐 뉴런을 자극하는 것으로 알려져 있다[9-11].

최근 Human Genome Project의 완성을 통한 인간의 게놈 을 분석한 결과에 의하면, 인간 개개인간에 $0.5 \%$ 까지 유전자 변이가 존재하는 것으로 알려져 있다. 특히, 가장 많은 비중을 차지하는 단일염기서열다형성(Single nucleotide polymorphism, $\mathrm{SNP}$ )의 경우, 현재까지 발굴된 $\mathrm{SNP}$ 는 약 400 만 개에 이르나, 추정되는 SNP 수는 1500 만개에 달하며 게놈 상에서 평균 200-300쌍마다 하나씩 존재하는 것으로 알려져 있다(http://

\footnotetext{
*Corresponding author

Tel : +82-53-950-5353, Fax : +82-53-953-3066

E-mail : kimuk@knu.ac.kr

${ }^{+}$These authors contributed equally in this study.
}

www.ncbi.nlm.nih.gov/snp). SNP을 비롯한 유전적 변이는 각 개인이 타고나는 생김새, 성격, 질병에 대한 감수성, 그리고 약물에 대한 반응의 차이를 일으키는 요인으로 중요성이 대두 됨에 따라 천식, 동맥경화, 알쯔하이머, 암 등 주요 질병의 원 인 유전자 발굴을 위한 유전자 분석의 표지자(marker)로 활발 하게 사용되고 있다. 이와 같은 $\mathrm{SNP}$ 을 이용한 유전자 변이와 인간 표현형과의 관련성에 대한 연구는 의 - 약학 분야뿐만 아니라, 일상생활에서도 쉽게 찾을 수 있게 되었다. 대표적인 예가 phenylthiocarbamide (PTC)를 비롯한 쓴맛물질에 대한 각 개인간의 민감도(sensitivity)차이가 미각수용체 유전자 내 에 존재하는 $\mathrm{SNP}$ 또는 서로 연관되어 있는 $\mathrm{SNP}$ 들의 조합인 일배체형(haplotype)에 의해 결정하는 사실이 밝혀짐으로써 관련 학문 분야에서 SNP연구의 중요성이 더욱 커지고 있다 $[1,2,4,5]$.

이러한 관점에서 볼 때, 단맛을 담당하는 TAS1R2 및 TAS1R3 수용체에 존재하는 유전자변이가 단맛물질을 느끼는 인간의 민감도차이에 영향을 미칠 가능성이 있다고 할 수 있 다[6-8]. 특히, 당류, 아스파탐(aspartame), 모넬린(monelin) 등 대부분의 단맛물질과의 결합에는 TAS1R2 유전자의 $\mathrm{N}$-말단이 중요한 역할을 담당하는 것으로 알려져 있다[11]. 따라서, 한국 인을 대상으로 단맛물질에 대한 민감도에 차이를 느끼는데 유전적 요인이 있는지를 알아보기 위해서는 우선 TAS1R2 유 전자 내에 존재하는 $\mathrm{SNP}$ 을 찾을 필요가 있다고 판단되어 한국 인 98명을 대상으로 염기서열분석법을 이용한 유전자분석을 수행하고자 하였다. 


\section{재료 및 방법}

\section{대상 및 Genomic DNA 추출}

본 연구는 만20세 이상의 성인남녀 98 명을 대상으로 본인의 동의 하에 말초혈액에서 $10 \mathrm{ml}$ 의 정맥혈을 채혈하여 Qiagen FlexiGene DNA kit를 이용하여 genomic DNA를 추출하였다. 각 DNA의 양은 분광계(spectrometer)로 측정하여 $25 \mathrm{ng} / \mu \mathrm{l}$ 로 균일하게 희석시켜, agarose gel 전기영동기를 이용하여 DNA 의 질을 알아보았다.

\section{중합효소연쇄반응(Polymerase Chain Reaction, PCR)}

TAS1R2 유전자의 5' 비전사암호화부위(untranslated region, UTR), 암호화부위(coding region 또는 exon), 그리고 3`UTR에 특이한 프라이머를 제작하여 다음과 같은 조건으로 실험을 수행하였다. 각 중합효소연쇄반응(PCR)은 $25 \mathrm{ng}$ template genomic DNA, $2.5 \mu \mathrm{l} 10 \times$ PCR reaction buffer, 1.5-2 $\mathrm{mM} \mathrm{MgCl} 2,0.2 \mu \mathrm{M}$ dNTP, $15 \mathrm{pmol}$ 양쪽 primers, $0.75 \mathrm{u} \mathrm{Taq}$

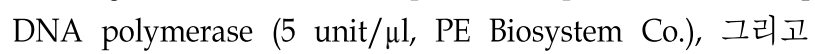
$\mathrm{dH}_{2} \mathrm{O}$ 를 넣어 final volume $25 \mu \mathrm{l}$ 를 맞춘 후 잘 섞은 다음 반응 을 시행하였다. 각 $\mathrm{PCR}$ cycle은 $95^{\circ} \mathrm{C}$ 에서 2 분간 denaturation 시킨 후, $94^{\circ} \mathrm{C}$ 에서 30 초, 각 primers의 $\mathrm{Tm}$ 온도에 따라 30 초, $72^{\circ} \mathrm{C}$ 에서 1 분간의 조건으로 35 cycles, 그리고 $72^{\circ} \mathrm{C}$ 에서 10 분 으로 최종 합성하였다.

\section{유전자 변이 분석 및 일배체형(haplotype) 구축}

PCR product에 대한 염기서열 결정은 $\mathrm{ABI} 3130 \mathrm{XL}$ 자동염기 서열 분석기를 이용하며, DNA Sequencing Analysis software (ver. 5.0)로 분석하였다. 유전자 변이 분석은 LASERGENESeqMan 및 PHRED/PHRAP/CONSED software suite를 이 용하여 알아내었다. 각 유전자에 대한 일배체형(haplotype)은 동형접합체(homozygotes)나 PHASE 2.0.2프로그램을 이용하
여 추론하였다.

\section{결과 및 고찰}

한국인 집단에서 TAS1R2 유전자에 존재하는 $\mathrm{SNP}$ 을 알아 내기 위하여 6 개의 암호화 부위 및 $5^{\prime}$ 과 $3^{\prime}$ 비암호화전사부위에 대한 프라이머를 작성, $\mathrm{PCR}$ 로 증폭하여 염기서열결정 방법으 로 분석하였다. Table 1에 제시된 바와 같이, 12 개의 $\mathrm{SNP}$ 이 검출되었으며, Hardy-Weinberg 평형을 벗어나는 $\mathrm{SNP}$ 은 존 재하지 않았다. 이 중 9 종류의 $\mathrm{SNP}$ 은 암호화 부위에서 발견되 었으며 2 종류의 SNP은 프로모터 부위에 존재하였다. 또한, 검출된 SNP들 중 231 번째와 950 번째 염기가 치환된 2 개의 $\mathrm{SNP}$ 은 본 연구에서 처음으로 관찰된 새로운 $\mathrm{SNP}$ 들로써, 한국 인집단에서 특이적으로 발견되는 변이일 가능성이 높다고 할 수 있다. 그리고, 암호화 부위에서 발견된 SNP들 중 약 $70 \%$ 가 아미노산의 변화를 초래하는(nonsynonymous) 유전자변이로 확인되었다. 이는 한국인 집단에서의 TAS1R2 유전자 내에 존 재하는 아미노산치환변이의 비율이 상대적으로 다른 유전자 들보다 높다는 Kim 등[3]의 연구와 일치된다고 할 수 있다. 특히 본 연구에서 발견된 대부분의 아미노산치환변이가 맛물 질과의 결합부위에 해당되는 $\mathrm{N}$-말단부위에서 존재한다는 사 실은 이들 아미노산치환이 맛물질과의 결합력에 영향을 미칠 가능성이 높은 기능적인 $\mathrm{SNP}$ 일 수 있다는 점을 시사해준다고 할 수 있다.

또한, 기존의 Kim 등[5] 연구에 따르면, 각 $\mathrm{SNP}$ 보다 검출된 염기 서열 변이의 조합으로 생성되는 일배체형이 맛물질에 대한 민감도차이를 결정한다는 사실이 잘 알려진 바, 본 연구 에서는 암호화 부위에서 발견된 SNP들에 대한 일배체형을 구 축하였다. Table 2에 나타난 바와 같이, 총 20 종류의 서로 다른 일배체형이 존재하였으며 이 중 세 종류의 일배체형이 전체의 약 $70 \%$ 를 차지하였다. 한국인 집단에서 공통적으로 존재하는

Table 1. The SNPs and their frequencies of $h T A S 1 R 2$ gene in Koreans

\begin{tabular}{|c|c|c|c|c|c|c|c|c|c|c|}
\hline \multirow{2}{*}{ Gene } & \multirow{2}{*}{$\begin{array}{l}\text { Chro } \\
\text { mosome }\end{array}$} & \multirow{2}{*}{ Location } & \multirow{2}{*}{ SNP ID } & \multirow{2}{*}{$\begin{array}{c}\text { Variant } \\
\text { (Amino acid change) }\end{array}$} & \multirow{2}{*}{$\begin{array}{l}\text { Nucleotide } \\
\text { change }\end{array}$} & \multirow{2}{*}{$\begin{array}{l}\text { Codon } \\
\text { position }\end{array}$} & \multicolumn{2}{|c|}{ Allele frequency } & \multicolumn{2}{|c|}{ Heterozygosity } \\
\hline & & & & & & & Major & Minor & Expected & Objected \\
\hline \multirow[t]{12}{*}{ TAS1R2 } & 1 & Promotor & rs9701803 & promotor-165 C >G & - & - & $0.67(\mathrm{C})$ & 0.33 & 0.444 & 0.476 \\
\hline & & & rs9700646 & promotor-105 C>T & - & - & $0.50(\mathrm{~T})$ & 0.50 & 0.476 & 0.435 \\
\hline & & Exon1 & rs9701796 & S9C & $\mathrm{C} 26 \mathrm{G}$ & 2 & $0.67(\mathrm{C})$ & 0.33 & 0.456 & 0.481 \\
\hline & & Exon2 & novel & F77L & $\mathrm{T} 231 \mathrm{G}$ & 3 & $0.81(\mathrm{~T})$ & 0.19 & 0.293 & 0.262 \\
\hline & & Exon3 & rs35874116 & I191V & A571G & 1 & $0.77(\mathrm{~A})$ & 0.23 & 0.311 & 0.282 \\
\hline & & & rs 28470550 & $\mathrm{~T} 294 \mathrm{~T}$ & T882G & 3 & $0.95(\mathrm{~T})$ & 0.05 & 0.227 & 0.043 \\
\hline & & & rs34447754 & R317G & G949C & 1 & $0.81(\mathrm{G})$ & 0.19 & 0.306 & 0.289 \\
\hline & & & novel & R317P & G950C & 2 & $0.90(\mathrm{G})$ & 0.10 & 0.18 & 0.2 \\
\hline & & Intron3 & rs28592077 & IVS3+42 G>A & - & - & $0.83(\mathrm{G})$ & 0.17 & 0.206 & 0.14 \\
\hline & & Exon4 & rs28374389 & $\mathrm{I} 486 \mathrm{~V}$ & A1456G & 1 & $0.95(\mathrm{~T})$ & 0.05 & 0.043 & 0.043 \\
\hline & & Exon6 & rs12033832 & S773S & C2319T & 3 & $0.60(\mathrm{~T})$ & 0.40 & 0.493 & 0.5 \\
\hline & & & rs12075191 & I790I & C2370T & 3 & $0.90(\mathrm{C})$ & 0.10 & 0.191 & 0.214 \\
\hline
\end{tabular}


Table 2. Haplotypes and their frequencies of hTAS1R2 gene in Koreans

\begin{tabular}{|c|c|c|c|c|c|c|c|c|c|}
\hline \multirow{2}{*}{ Haplotype } & \multicolumn{8}{|c|}{ Nucleotide position } & \multirow{2}{*}{ Frequency } \\
\hline & $26(n)$ & $231(\mathrm{~s})$ & $571(\mathrm{n})$ & 882(s) & 949(n) & 950(n) & $2319(\mathrm{~s})$ & $2370(\mathrm{~s})$ & \\
\hline 1 & $\mathrm{C}$ & $\mathrm{T}$ & $\mathrm{A}$ & $\mathrm{T}$ & G & G & $G$ & G & 0.225 \\
\hline 2 & G & $\mathrm{T}$ & $\mathrm{A}$ & $\mathrm{T}$ & G & G & G & G & 0.088 \\
\hline 3 & $\mathrm{C}$ & $\mathrm{T}$ & $\mathrm{A}$ & G & G & G & G & G & 0.010 \\
\hline 4 & G & $\mathrm{C}$ & G & $\mathrm{T}$ & $\mathrm{C}$ & G & G & G & 0.010 \\
\hline 5 & $\mathrm{C}$ & $\mathrm{C}$ & G & G & $\mathrm{C}$ & G & G & G & 0.010 \\
\hline 6 & G & $\mathrm{C}$ & G & G & $\mathrm{C}$ & G & $\mathrm{G}$ & G & 0.015 \\
\hline 7 & $\mathrm{C}$ & $\mathrm{C}$ & G & G & $\mathrm{C}$ & $\mathrm{C}$ & G & G & 0.031 \\
\hline 8 & $\mathrm{C}$ & $\mathrm{T}$ & $\mathrm{A}$ & $\mathrm{T}$ & G & G & $\mathrm{A}$ & G & 0.316 \\
\hline 9 & G & $\mathrm{T}$ & A & $\mathrm{T}$ & G & G & A & G & 0.102 \\
\hline 10 & G & C & A & $\mathrm{T}$ & G & G & A & G & 0.005 \\
\hline 11 & $\mathrm{C}$ & $\mathrm{T}$ & A & G & G & G & A & G & 0.020 \\
\hline 12 & $\mathrm{C}$ & C & A & G & G & G & A & G & 0.005 \\
\hline 13 & $\mathrm{G}$ & C & G & $\mathrm{T}$ & $\mathrm{C}$ & G & A & G & 0.005 \\
\hline 14 & G & C & G & G & $\mathrm{C}$ & G & $\mathrm{A}$ & G & 0.010 \\
\hline 15 & $\mathrm{C}$ & C & G & $\mathrm{T}$ & $\mathrm{C}$ & C & A & G & 0.036 \\
\hline 16 & G & C & G & G & $\mathrm{C}$ & C & A & G & 0.010 \\
\hline 17 & $\mathrm{C}$ & $\mathrm{T}$ & $\mathrm{A}$ & $\mathrm{T}$ & G & G & $\mathrm{G}$ & $\mathrm{A}$ & 0.036 \\
\hline 18 & G & $\mathrm{T}$ & A & $\mathrm{T}$ & G & G & G & A & 0.041 \\
\hline 19 & G & $\mathrm{C}$ & G & $\mathrm{T}$ & $\mathrm{C}$ & G & G & A & 0.005 \\
\hline 20 & G & C & G & G & C & G & G & A & 0.020 \\
\hline
\end{tabular}

일배체형의 차이는 첫 번째 존재하는 p.S9C 아미노산변이가 다르다는 사실은 이 치환으로 인한 맛물질과의 결합차이가 일어날 가능성이 높음을 제시해 준다고 할 수 있으며 이 유전 자형에 따른 민감도차이를 알아볼 필요가 있다고 사료된다.

최근 서구화된 식생활, 그로 인한 비만, 당뇨 등과 같은 질환 이 현대사회에서 높은 빈도로 발생하고 있으며 이에 대한 예 방에 대한 관심이 급격히 증가하고 있다. 특히, 개인의 유전자 형에 따른 대사차이를 연구하는 영양유전학분야가 새로운 학 문으로 각광받기 시작하고 있는 이 시점에서 단맛을 결정하는 데 중요한 역할을 담당하는 TAS1R2 유전자에 대한 한국인의 유전적 요인에 대한 본 연구는 앞으로 유전자형에 다른 개인 간의 단맛 민감도 차이에 과연 유전자형이 얼마나 관여하는지 여부를 알아보는데 중요한 기초자료로 유용될 수 있다고 생각 되며 추후 단맛물질에 대한 관능 검사 시 주요지표로 이용될 수 있으리라 판단된다.

\section{감사의 글}

이 논문은 2008년도 정부재원(교육인적자원부 학술연구조 성비)으로 한국학술진흥재단의 지원을 받아 연구되었음(KRF2008-314-F00056).

\section{References}

1. Bufe, B., P. A. Breslin, C. Kuhn, D. R. Reed, C. D. Tharp,
J. P. Slack, U. K. Kim, D. Drayna, and W. Meyerhof. 2005. The molecular basis of individual differences in phenylthiocarbamide and propylthiouracil bitterness perception. Curr. Biol. 15, 322-327.

2. Bufe, B., T. Hofmann, D. Krautwurst, J. D. Raguse, and W. Meyerhof. 2002. The human TAS2R16 receptor mediates bitter taste in response to beta-glucopyranosides. Nat. Genet. 32, 397-401.

3. Kim, U., S. Wooding, D. Ricci, L. B. Jorde, and D. Drayna. 2005. Worldwide haplotype diversity and coding sequence variation at human bitter taste receptor loci. Hum Mutat. 26, 199-204.

4. Kim, U. K. and D. Drayna. 2005. Genetics of individual differences in bitter taste perception: lessons from the PTC gene. Clin. Genet. 67, 275-280.

5. Kim, U. K., E. Jorgenson, H. Coon, M. Leppert, N. Risch, and D. Drayna. 2003. Positional cloning of the human quantitative trait locus underlying taste sensitivity to phenylthiocarbamide. Science 299, 1221-1225.

6. Kitagawa, M., Y. Kusakabe, H. Miura, Y. Ninomiya, and A. Hino. 2001. Molecular genetic identification of a candidate receptor gene for sweet taste. Biochem Biophys. Res. Commun 283, 236-242.

7. Liao, J. and P. G. Schultz. 2003. Three sweet receptor genes are clustered in human chromosome 1. Mamm Genome 14, 291-301.

8. Mennella, J. A., M. Y. Pepino, and D. R. Reed. 2005. Genetic and environmental determinants of bitter perception and sweet preferences. Pediatrics 115, e216-222.

9. Nelson, G., J. Chandrashekar, M. A. Hoon, L. Feng, G. Zhao, 
N. J. Ryba, and C. S. Zuker. 2002. An amino-acid taste receptor. Nature 416, 199-202.

10. Nelson, G.., M. A. Hoon, J. Chandrashekar, Y. Zhang, N. J. Ryba, and C. S. Zuker. 2001. Mammalian sweet taste receptors. Cell 106, 381-390.

11. Zhao, G. Q., Y. Zhang, M. A. Hoon, J. Chandrashekar, I. Erlenbach, N. J. Ryba, and C. S. Zuker. 2003. The receptors for mammalian sweet and umami taste. Cell 115, 255-266.

\section{초록 : 한국인의 단맛수용체유전자 TAS1R2 다형성분석 및 일배체형 연구}

이혜진 ${ }^{\dagger}$ 배재웅 ${ }^{\dagger}$ 권태준 · 사공보름 · 김언경*

(경북대학교 생물학과)

단맛은 인간이 느낄 수 있는 다섯 가지 감각 중 하나로, 열량을 제공하며 식욕을 결정하는데 중요한 요인이다. 인간이 맛물질을 느끼는 민감도 차이에 유전적인 요인이 중요한 역할을 한다는 사실이 알려진 바, 본 연구에서는 한국인 98명을 대상으로 단맛을 결정하는 미각수용체 TAS1R2 유전자에 대해 염기서열분석법을 이용한 단일염기 다형성 종류 및 빈도, 그리고 일배체형 분석을 수행하였다. 그 결과, TAS1R2 유전자로부터 총 12 종류의 SNP이 검출되었으며 약 $70 \%$ 는 아미노산 치환을 일으키는 변이로 확인되었다. 특히, 231번째와 950 번째 변이는 본 연구 를 통해 처음으로 발견된 새로운 것으로 한국인 집단에서 특이적으로 존재하는 $\mathrm{SNP}$ 일 가능성이 높다고 판단된 다. 일배체형 분석결과에 따르면, 발견된 20 종류 일배체형 중 세 가지가 주로 한국인이 가지는 것으로 확인되었 다. 본 연구결과 발견된 TAS1R2 유전자의 $\mathrm{SNP}$ 은 향후 단맛물질을 감지하는 인간의 민감도차이를 결정하는데 유전적 요인으로 작용하는지 알아보는데 중요한 기초자료를 제시해 주리라 생각되며 맞춤형 식단 등 영양유전학 분야에 응용될 수 있을 것이다. 